\title{
RELATIONSHIPS AMONG SOME TYPE TRAITS IN CZECH PIED CATTLE
}

\author{
G. Chládek, J. Kučera
}

Received: February 8, 2006

\begin{abstract}
CHLÁDEK, G., KUČERA, J.: Relationships among some type traits in Czech Pied Cattle. Acta univ. agric. et silvic. Mendel. Brun., 2006, LIV, No. 2, pp. 53-58

A dataset of 27787 first-lactation cows with a minimum of $51 \%$ of Czech Pied cattle in genotype (CA) was analysed with the aim to evaluate relationships among type traits and characteristics. The dataset included a sub-population of 5796 pure-bred Czech Pied cows (CP). Linear type traits and general type characteristics were evaluated. The following 17 linear type traits were scored (on the scale of 1-9): stature (LP 1), rump muscularity (LP 2), rump length (LP 3), rump width (LP 4), rump angle (LP 5), body depth (LP 6), rear legs set (LP 7), hock (LP 8), foot angle (LP 9), hoof (LP 10), udder length - fore quarters (LP 11), rear udder height (LP 12), central ligament (LP 13), udder depth (LP 14), teat placement (LP 15), teat length (LP 16) and teat thickness (LP 17). The four general type characteristics (the score 50-100) were as follows: frame (E 1), muscularity (E 2), legs/feet (E 3) and mammary (E 4).

The highest coefficients of correlation among linear type traits $(r>0.5)$ in $\mathrm{CA}$ and $\mathrm{CP}$, respectively, were found between LP 3 and LP 4 ( 0.720 and 0.725 , respectively), LP 1 and LP 3 ( 0.510 and 0.516 , respectively), LP 1 and LP 6 ( 0.526 and 0.535 , respectively) and LP 4 and LP 6 ( 0.503 and 0.492 , respectively). The highest coefficients of correlation $(\mathrm{r}>0.5)$ between linear type traits and general type characteristics were found in CA and CP, respectively, between E 2 and LP 1 (0.958 and 0.956, respectively), E 1 and LP 1 ( 0.835 and 0.833 , respectively), E 1 and LP 6 ( 0.753 and. 0.756, respectively), E 1 and LP 3 ( 0.750 and 0.758 , respectively), E 1 and LP 4 (0.744 and 0.755, respectively), E 4 and LP 11 ( 0.720 and 0.713 , respectively) and E 4 and LP 12 ( 0.716 and 0.744 , respectively). No coefficient of correlation between general type characteristics was greater than 0.5 . No significant differences were found (maximum difference 0.147 ) between the coefficients of correlation in the whole population (CA) and in the pure-bred sub-population $(\mathrm{CP})$.
\end{abstract}

type, Czech Pied Cattle, first-calvers, linear assessment

Major criteria in cow selection are milk quantity and quality, and good conformation which is essential for repeatability of high milk production in subsequent lactations (MOXLEY, 1984). STRAPÁK and AUMANN (1998) found significant positive relationships among type and production traits in Fleckvieh cows in Bavaria.

STRAPÁK et al. (2005) analysed relationships between type and longevity traits in Fleckvieh cows in Bavaria. They found out that the conformation score for the form and for the udder showed positive correlations with longevity traits.

BOUŠKA et al. (1999) looked into linear type traits genetic evaluations in Czech Pied cattle. They found the highest genetic correlations between body depth and body capacity resp. type harmony $(0.69$ and 0.68 , respectively), body depth and muscularity $(0.58)$, frame and body capacity ( 0.63$)$, fore and rear udder form (0.50). The highest correlations were found between production type and the rest of the traits $(0.65-0.85)$. 
KUČERA et al. (2002) analysed the relationships between linear type traits and type classification and breeding values of milk production in Holstein cattle. The authors found the highest phenotypic correlations in general characteristics for mammary and dairy character, however no value exceeded 0.50.

Genetic and phenotypic parameters for type and production in Guernsey dairy cows were analyzed by HARRIS et al. (1992). Their results suggested that a selection for improvement of milk production would lead to correlated increases in dairy form, rear udder height, rear udder width, and udder depth and correlated decreases in the strength of udder attachment. The highest phenotypic correlations were found between stature and strength and thurl width, respectively (both 0.53 ), strength and body depth and thurl width, respectively $(0.67$ and 0.77$)$, dairy form and rear udder width $(0.58)$, thurl width and body depth $(0.57)$ and between rear udder width and rear udder height (0.62).

Genetic parameters of conformation traits, milk yield, and herd life in Holstein were analyzed by SHORT and LAWLOR (1992). The highest phenotypic coefficients of correlation $(r>0.50)$ were found between body depth and stature and. strength, respectively $(0.65$ and 0.77$)$, stature and strength $(0.58)$, and between udder height and udder width (0.71).

Phenotypic and genetic relationships between linear functional type traits and milk yield in five breeds (Ayrshire, Brown Swiss, Guernsey, Jersey and Milking Shorthorn) were analyzed by NORMAN et al. (1988). High values of phenotypic coefficients of correlation $(r>0.5)$ were found between stature and strength in Ayrshire (0.61), Milking Shorthorn (0.64), Guernsey (0.59) and Jersey (0.56) and between rear udder width and rear udder height in Milking Shorthorn (0.73), Guernsey (0.61), Jersey (0.54) and Brown Swiss (0.61).

The aim of this study was to evaluate relationships among some type traits and characteristics in Czech Pied first-lactation cows.

\section{METHODS AND MATERIAL}

A dataset of 27787 first-lactation cows with a minimum of $51 \%$ of Czech Pied cattle in genotype (CA) was analysed. The dataset included a sub-population of 5796 purebred Czech Pied cows (CP). Type classification had two components, linear type traits evaluation (scored on the scale of 1-9) marked LP 1 to LP 17 (see Fig. 1 Chart of linear type traits) and the assessment of four functional areas of the cow used for calculation of the final score and grade marked $\mathrm{E} 1$ to $\mathrm{E} 4$. The following linear type traits were assessed: stature (LP 1), rump muscularity (LP 2), rump length (LP 3), rump width (LP 4), rump angle (LP 5), body depth (LP 6), rear legs set (LP 7), hock (LP 8), foot angle (LP 9), hoof (LP 10), udder length - fore quarters (LP 11), rear udder height (LP 12), central ligament (LP 13), udder depth (LP 14), teat placement (LP 15), teat length (LP 16) and teat thickness (LP 17). The four general type characteristics (the score 50-100) were as follows: frame (E 1), muscularity (E 2), legs/ feet (E 3) mammary (E 4).

Relationships between the observed linear type traits and general type characteristics were described by phenotypic coefficients of correlation calculated with the use of SAS programme.

\section{RESULTS}

Phenotypic coefficients of correlation among the observed type traits and characteristics in first-calvers (CA and CP) are presented in Table I. Values describing the whole dataset $(n=27787)$ are shown above diagonal and the values concerning the sub-population of purebred cows (5796) can be found below diagonal.

With regard to the relationships between linear type traits and general type characteristics, the highest coefficients of correlation $(r>0.5)$ in the whole population and in the sub-population, respectively (CA and $\mathrm{CP}$, respectively) were found between muscularity (E 2) and rump muscularity (LP 2, r $=0.958$ and 0.956 , respectively); between frame (E 1) and: stature (LP 1, r $=0.835$ and 0.833 , respectively); body depth (LP 6, r $=0.753$ and 0.756 , respectively); rump length (LP 3, r $=0.750$ and 0.758 , respectively) and rump width (LP 4, $r=0.744$ and 0.755 , respectively). High coefficients of correlation were also found between mammary (E 4) and udder length - fore quarters (LP 11, r $=0.720$ and 0.713 , respectively) and rear udder height (LP 12, r $=0.716$ and 0.744 , respectively).

With regard to the relationships among linear type traits, the highest coefficients of correlation $(r>0.5)$ were found between rump length (LP 3) and rump width (LP 4, r $=0.720$ and 0.725 , respectively), stature (LP 1) and body depth (LP 6, r $=0.526$ and 0.535 , respectively) and rump length (LP $3, r=0.510$ and 0.516 , respectively).

With regard to the relationships among general type characteristics, no coefficient of correlation was higher than 0.5 . The highest value $(r=0.357$ and 0.367 , respectively) in $\mathrm{CA}$ and $\mathrm{CP}$, respectively, was found between muscularity (E 2) and frame (E 1).

Table I also indicates that the highest difference in the coefficients of correlation between identical characteristics in the two populations (CA and $\mathrm{CP}$ ) was 0.147 (between udder depth-LP 14 and teat thicknessLP 17). 


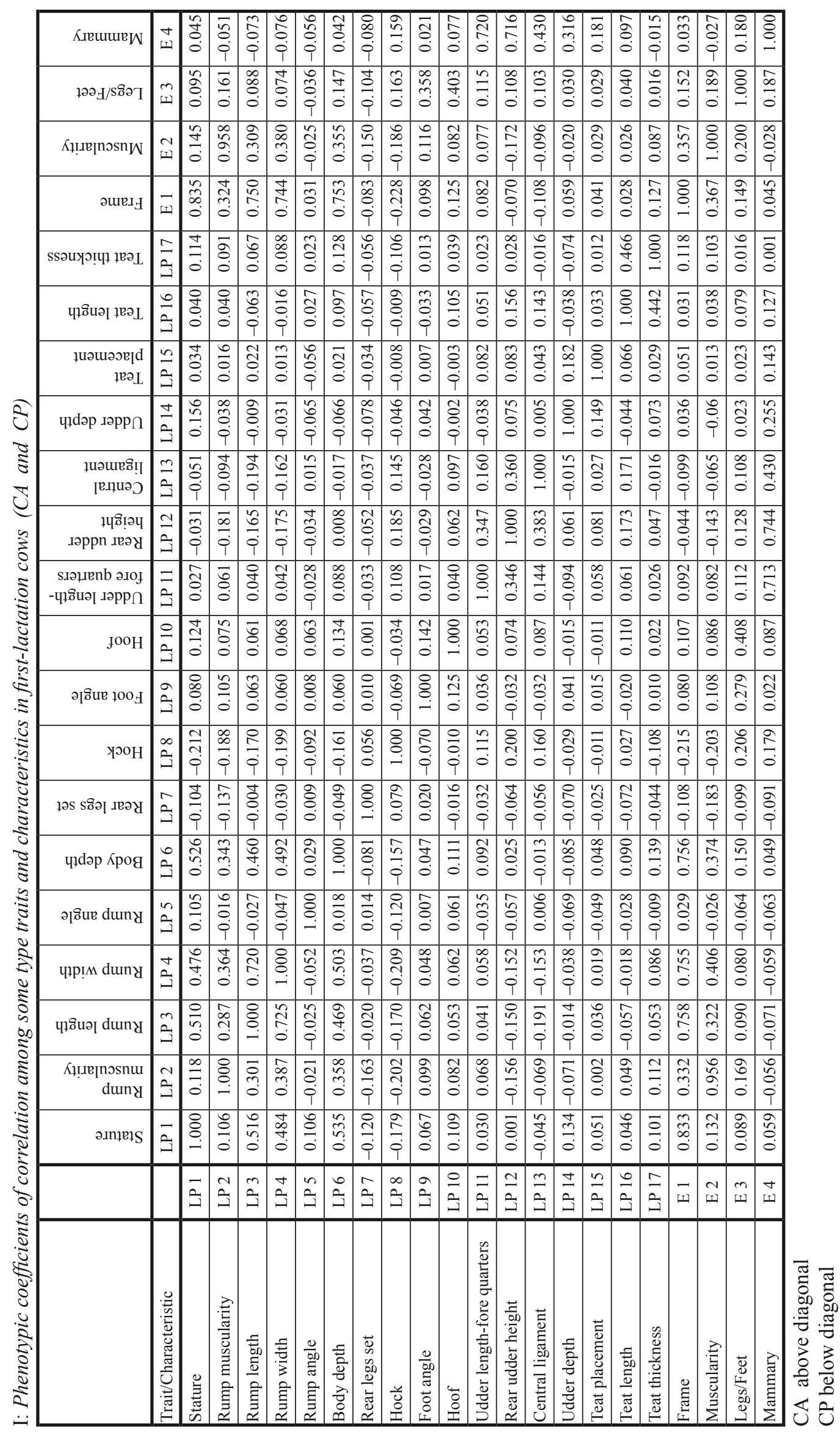




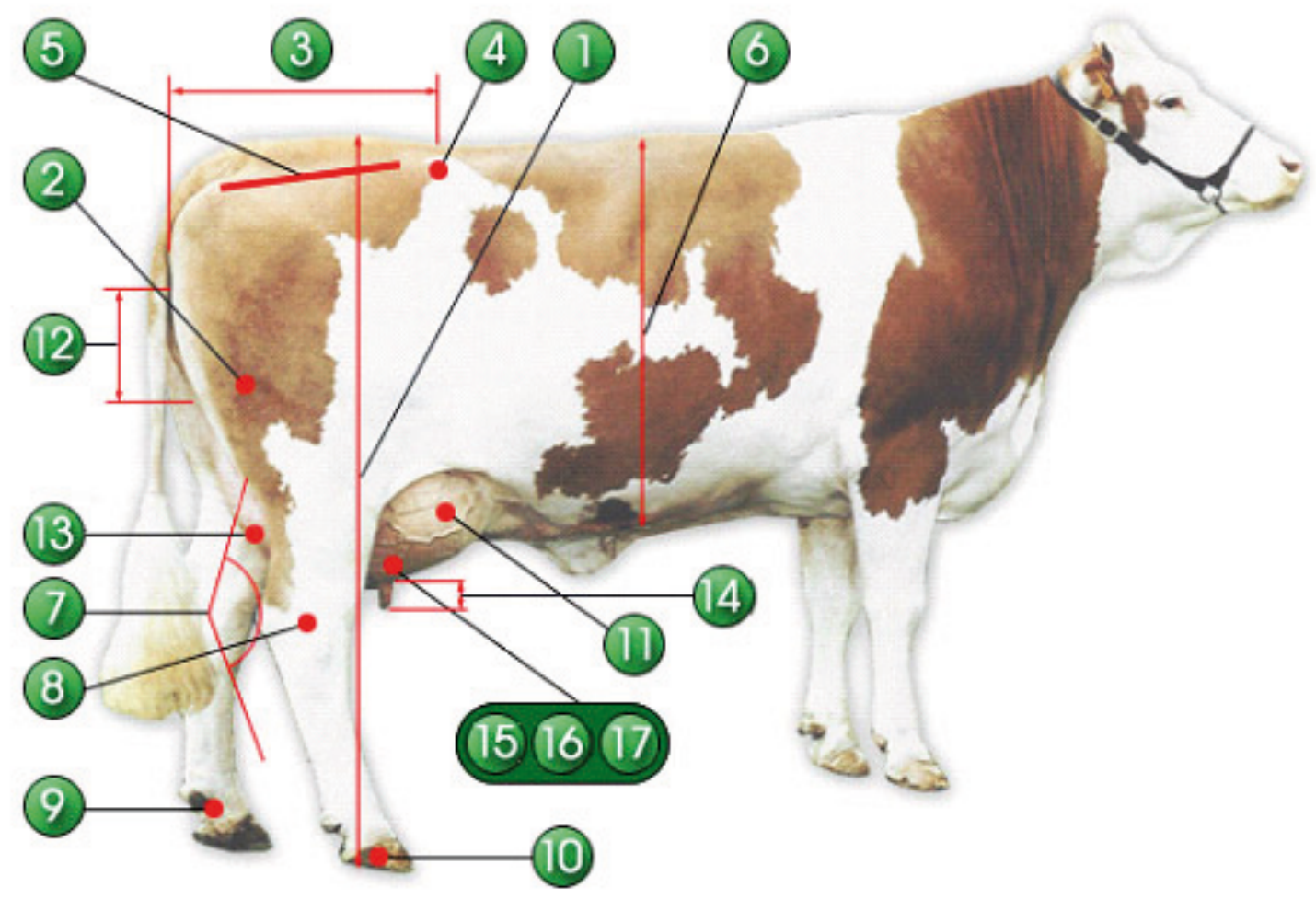

\section{1: Chart of linear type traits}

LP 1 Stature - výška v křízi

LP 2 Rump muscularity - osvalení kýty

LP 3 Rump lenght - délka zádě

LP 4 Rump width - šiřka zádě v kyčlích

LP 5 Rump angle - sklon zádě

LP 6 Body depth - hloubka středotrupí

LP 7 Rear legs set - postoj zadních končetin

LP 8 Hock - charakter hlezenního kloubu

LP 9 Foot angle - spěnka

LP 10 Hoof - paznehty

\section{DISCUSSION}

The relationships among the observed type characteristics were undoubtedly affected by their optimum value which has an impact on the distribution of the values in the population. The type characteristics can be divided into two groups according to the optimum value. The characteristics of which the maximum value is optimal form the first group. They include all of the general type characteristics (E 1-E 4) and the following linear type traits: stature (LP 1), rump muscularity (LP 2), rump length (LP 3), rump width (LP 4), body depth (LP 6), udder length - fore quarters (LP 11), rear udder height (LP 12), central ligament (LP 13) and udder depth (LP 14). In the rest of the linear type traits - rear legs set (LP 7), hock
LP 11 Udder length - fore quarters - délka vemene (přední čtvrtě)

LP 12 Rear udder height - nasazení vemene (zadní upnutí)

LP 13 Central ligament - závěsný vaz

LP 14 Udder depth - základna vemene (hloubka)

LP 15 Teat placement - postavení struků

LP 16 Teat length - délka struků

LP 17 Teat thickness - tloušt'ka struků
(LP 8), foot angle (LP 9), hoof (LP 10), teat placement (LP 15), teat length (LP 16) and teat thickness (LP 17) mean values (or close to mean, as in rump angle LP 5) are optimal. This fact implies that high coefficients of correlation can be expected neither among these characteristics nor between them and other type characteristics. Table I well reflects this as there is no coefficient of correlation higher than 0.4 , except the correlation between teat length and thickness. However, this value suggests that short teats tend to be thick while long teats tend to be thin in the observed population.

Significant relationships between frame and stature or body depth were confirmed by results of BOUŠKA et al. (1999), HARRIS et al. (1992), SHORT and 
LAWLOR (1992) or NORMAN et al (1988). Our significant relationships between frame and rump width and length are not so explicit in the literature and are only described by HARRIS et al. (1992). They also presented similar results regarding mammary which was significantly correlated with udder length - fore quarters and rear udder height. High coefficients of correlation between rump width and length suggest that the cows in our population had either narrow and short or wide and long rumps.

Most quoted authors presented high coefficients of correlation between udder linear traits. SHORT and LAWLOR (1992) presented the highest value (0.71). Our values were lower, the highest 0.347 and 0.360 respectively, were found between udder length - fore quarters and rear udder height and between rear udder height and central ligament, respectively, in the whole experimental population. The corresponding values for the purebred animals were 0.346 and 0.383 , respectively. This difference was probably caused by the different production type of experimental animals. We analysed dual-purpose cattle while other authors analysed specialised dairy cattle, except for BOUŠKA et al. (1999) whose values (0.50) were therefore similar to ours.

Unusually high coefficients of correlation $(0.958$ for CA and 0.956 for $\mathrm{CP}$ ) between general muscularity and linear type trait rump muscularity reflects the importance of rump muscularity for the overall muscularity of an animal. However, the value close to 1.0 brings up a question whether the evaluation of general muscularity should also take into consideration muscularity of some other body areas (e.g. back or shoulder), although not so important, beside rump muscularity.

\section{SOUHRN}

Vztahy mezi vybranými charakteristikami exteriéru dojnic českého strakatého plemene skotu S cílem zhodnotit vztahy mezi vybranými charakteristikami exteriéru byl analyzován soubor 27787 kusů (CA) prvotelek s podílem minimálně $51 \%$, resp. 5796 kusů $(\mathrm{CP})$ se $100 \%$ podílem krve českého strakatého plemene. Vybranými charakteristikami exteriéru byly jednak hodnoty lineárního popisu znaků zevnějšku, jednak hodnoty výsledných charakteristik hodnocení exteriéru. V rámci lineárního popisu zevnějšku (1 až 9 bodů) bylo sledováno následujících 17 znaků: výška v kř́žži (LP 1), osvalení kýty (LP 2), délka zádě (LP 3), šířka zádě v kyčlích (LP 4), sklon zádě (LP 5), hloubka středotrupí (LP 6), postoj zadních končetin (LP 7), charakter hlezenního kloubu (LP 8), spěnka (LP 9), paznehty (LP 10), délka vemene (přední čtvrtě) (LP 11), nasazení vemene (zadní upnutí) (LP 12), závěsný vaz (LP 13), základna vemene (hloubka) (LP 14), postavení struků (LP 15), délka struků (LP 16) a tloušt'ka struků (LP 17). V rámci výsledných charakteristik hodnocení exteriéru (50 až 100 bodů) byly sledovány čtyři souhrnné charakteristiky: rámec (E 1), osvalení (E 2), končetiny (E 3) a vemeno (E 4).

Vzájemné vztahy mezi vybranými charakteristikami exteriéru byly vyjádřeny pomocí fenotypových koeficientů korelace uvedených $\mathrm{v}$ Tab. I. Hodnoty nad diagonálou byly zjišsěny u celého souboru (CA), hodnoty pod diagonálou byly zjištěny u čistokrevné části populace (CP). Pokud se týká vzájemných vztahů mezi hodnotami lineárního popisu sledovaných znaků, byly nejvyšší hodnoty koeficientů korelace $(r>0.5)$ shledány u provotelek CA, resp. CP mezi LP 3 a LP $4(0,720$, resp. 0,725), LP 1 a LP 3 $(0,510$, resp. 0,516$)$, LP 1 a LP $6(0,526$, resp. 0,535$)$ a LP 4 a LP $6(0,503$, resp. 0,492). Pokud se týká vztahů mezi hodnotami lineárního popisu sledovaných znaků a výslednými charakteristikami exteriéru, byly nejvyšší hodnoty koeficientů korelace ( $r>0.5)$ shledány u provotelek CA, resp. CP mezi E 2 a LP 1 $(0,958$, resp. 0,956), E 1 a LP $1(0,835$, resp. 0,833), E 1 a LP $6(0,753$, resp. 0,756), E 1 a LP $3(0,750$, resp. 0,758), E 1 a LP $4(0,744$, resp. 0,755), E 4 a LP $11(0,720$, resp. 0,713), E 4 a LP 12 (0,716, resp. $0,744)$. Žádná z hodnot koeficientů korelace mezi výslednými charakteristikami exteriéru nebyla vy̌šś než 0,5 . Nebyly shledány významnější rozdíly ve sledovaných koeficientech korelace (maximální rozdíl $0,147)$ mezi celou populací prvotelek (CA) a čistokrevnou subpopulací (CP).

exteriér, české strakaté plemeno, prvotelky, lineární popis, vztahy

\section{ACKNOWLEDGEMENTS}

The study was supported by NAZV QF 4005. 


\section{REFERENCES}

BOUŠKA, J., ŠTÍPKOVÁ, M., BARTOŇ, L., JIRMÁNEK, M.: Genetic parameters estimates for linearly described traits and conformation evaluation of Czech pied cattle. Czech J. Anim. Sci., 1999, 44, 289-293.

HARRIS, B. L., FREEMAN, A. E., METZGER, E.: Genetic and phenotypic parameters for type and production in Guernsey dairy cows. J. Dairy Sci., 1992, 75, 1147-1153.

KUČERA, J., CHLÁDEK, G., ŽIŽLAVSKÝ, J.: Analysis of the relationships between linear type traits and breeding values of milk production parameters in Holstein dairy cows. Acta univ. Agric. Et silvic. Mendel. Brun., 2002, 50, 139-144.
MOXLEY, J.: What other traits can be measured. In: Bensmark 100, Toronto, 1984

NORMAN, H. D., POWELL, R. L., WRIGHT, J. R., CASSEL, B. G.: Phenotypic and genetic relationship between linear functional type traits and milk yield for five breeds. J. Dairy Sci., 1988, 71, 18801896.

SHORT, T. H., LAWLOR, T. J.: Genetic parameters of conforamtion traits milk yield and herd life in Holstein. J. Dairy Sci., 1992, 75, 1987-1998.

STRAPÁK, P., AUMANN, J.: Relations between the body conformation and commercial traits of cattle. Czech J. Anim. Sci., 1998, 43, 293-298.

STRAPÁK, P., CANDRÁK, J., AUMANN, J.: Relationship between longevity and selected production, reproduction and type traits. Czech J. Anim. Sci., 2005, 50, 1-6.

Doc. Ing. Gustav Chládek, CSc., Dr. Ing. Josef Kučera, Ústav chovu a šlechtění zvířat, Mendelova zemědělská a lesnická univerzita v Brně, Zemědělská 1, 61300 Brno, Česká republika 